\title{
Equal distribution of burdens in flood risk management
}

The application of the 'égalité principle' in the compensation regimes of the Netherlands, Flanders and France

Willemijn van Doorn-Hoekveld*

PhD student Utrecht Centre for Water, Oceans and Sustainability Law, Institute for Jurisprudence, Constitutional and Administrative Law, Faculty of Law, Economics and Governance, Utrecht University

\begin{abstract}
Flood risk management is an eminent example of a policy field in which the distribution of burdens and benefits takes place. Flood risks are distributed unequally among society and measures that reduce or prevent flood risks also distribute burdens and benefits. Flood risk management measures may infringe property rights that are protected by the Charter of Fundamental Rights of the European Union (art. 17 in conjunction with art. 52 (3) and European Convention on Human Rights (art. 1 First Protocol). The Charter and the Convention are a safety net for these infringements and form a basic demand of the domestic compensation regimes. The underlying principle of these European, but also domestic compensation regimes can be found in the French principle égalité devant les charges publiques [equality before public burdens]. A compensation regime can mitigate adverse effects offlood risk management. This paper scrutinises the domestic compensation regimes of the Netherlands, Flanders and France for loss caused by flood prevention and flood protection and flood recovery measures. It shows that burdens are unequally distributed, not only between the three jurisdictions, but also within the jurisdictions. It also shows that the égalite principle is not applied in a consistent way.
\end{abstract}

\section{Introduction}

Due to climate change and urbanisation, floods occur more frequently in Europe than previously. Socio-economic studies show a clear trend of more people affected by river floods. ${ }^{1}$ In many cases, the nature of floods is transboundary, as most major European rivers flow through multiple Member States. This stresses the need for Member States to cooperate and coordinate

* DOI 10.7590/187479817X14945955771984 1874-7981 2017 Review of European Administrative Law

$1 \quad$ R. Rojas, L. Feyen and P. Watkiss, 'Climate Change and River Floods in the European Union: Socio-Economic Consequences and the Costs and Benefits of Adaptation' (2013) 23 Global EnvironmentalChange 1737,1742 . 
measures within river basin districts. These considerations led to the establishment of the Floods Directive (FD) in 2007. ${ }^{2}$

The Preamble of the FD starts with the statement that floods not only have the potential to cause fatalities, such as displacement of people and damage to the environment, they also compromise economic development and undermine the economic activities of the Community (rec. 1). Among other things, the Directive respects the fundamental rights of; the right to life (art. 2 Charter of Fundamental Rights of the European Union (henceforth CFREU) and European Convention on Human Rights (henceforth ECHR)); the protection of property (art. 17 in conjunction with art. 52 (3) CFREU; and art. 1 First Protocol of the ECHR). These two rights can conflict when the protection of lives necessitates infringements of property rights, such as when the protection against floods demands the expropriation of privately held land in order to create an area that temporarily stores water.

The infringements of property rights in the case of flood risk management (FRM) are burdens that a small group of people must bear in order to benefit a larger group of people or, in some cases, the whole society. This unequal distribution of burdens is one of the distributional effects of FRM. The infringement of property rights can assume different proportions. In most cases, a compensation regime exists which creates the possibility for burdened parties to demand compensation. This compensation regime mitigates the unequal distribution of burdens. Article 1 First Protocol forms a basic demand that the compensation regimes should meet. ${ }^{3}$ Nevertheless, Member States are free to have their own set of compensation regimes.

The compensation of burdens influences the way distributional effects are spread among society, but economic and social scientists do not assess it. They merely focus on the efficiency of a specific measure or policy. ${ }^{4}$

In addition, the question about distributional effects plays a role in FRM. Until now, this role mainly has focused on so-called ex-post damage. However, distributional effects also play a role in other flood risk strategies: who bears the costs to prevent a flood from happening, and who benefits from this safety? In this regard, only parties that finance preventive measures, e.g. the taxpayer, are taken into account. This socio-economic research also takes into account

2 Directive 2007/60/EC of the European Parliament and of the Council of 23 October 2007 on the assessment and management of flood risks.

3 Although art. 17 of the Charter of Fundamental Right of the European Union protects the right to property, this article has not been subject to case law. Therefore, this paper uses Article 1 FP ECHR as frame of reference.

4 S.M. Tapsell and others, 'Vulnerability to Flooding: Health and Social Dimensions' (2002) 360 The RoyalSociety 1511; E. Penning-Rowsell and others, 'Estimating Injury and Loss of Life in Floods: A Deterministic Framework' (2005) 36 Natural Hazards 43; S.N. Jonkman and others, 'Integrated Hydronamic and Economic Modelling of Flood Damage in the Netherlands' (2008) 66 Ecological Economics 77; Rojas, Feyen and Watkiss. 
the saved costs by preventing a flood. The abovementioned legal distributional effects are, however, overlooked. This paper aims to fill this knowledge gap and identifies the burdens caused by measures specific for three flood risk strategies and the way these burdens are compensated and by whom.

The scholarly literature defines flood-risk management strategies differently. This paper uses the definitions of the FD:

- $\quad$ Prevention: preventing damage caused by floods by avoiding construction of houses and industries in present and future flood-prone areas; by adapting future developments to the risk of flooding; and by promoting appropriate land-use, agricultural and forestry practices;

- Protection: taking measures, both structural and non-structural, to reduce the likelihood of floods and/or the impact of floods in a specific location; 5

- Preparedness: informing the population about flood risks and what to do in the event of a flood;

- Emergency response: developing emergency response plans in the case of a flood;

- $\quad$ Recovery and lessons learned: returning to normal conditions as soon as possible and mitigating both the social and economic impacts on the affected population. ${ }^{6}$

This paper considers three jurisdictions: the Netherlands, France, and the Flemish Region in Belgium, which have specific compensation regimes that redistribute these burdens. ${ }^{\text {? }}$

In the Netherlands, Flanders and France three strategies dominate - prevention, protection and recovery. Each strategy is characterized by specific FRM measures. ${ }^{8}$ These measures might cause burdens, which are likely to be mitigated by a specific compensation regime.

In the course of time, policy makers can update, adapt or replace strategies. Studies in the Netherlands, Flanders and France show a shift from protection to prevention (figure 1). ${ }^{9}$ However, a shift of strategy implies a shift in measures

5 In the Communication of the Commission, the concept of mitigation is addressed as well. Looking at the strategies above, mitigation would fall within the 'protection' strategy. Per type of measure is indicated whether international coordination or information is necessary or not. For most of the measures in the prevention strategy, which concern land use and spatial planning measures, no international coordination or information is necessary. Only for management and maintenance programmes international coordination is necessary.

$6 \mathrm{COM}(2004) 472$ final.

7 For the sake of readability I will refer to these jurisdictions as 'countries'.

8 With one exemption: in the recovery strategy, not man-made measures form the cause of the damage, but the flood does.

9 M. Kaufmann and others, Analysing and Evaluating Flood Risk Governance in the Netherlands. Drowning in Safety (STAR-FLOOD Consortium 2016); C. Larrue and others, Analysing and Evaluating Flood Risk Governance in France: From State Policy to Local Strategies (STAR-FLOOD Consortium 2016); H. Mees and others, 'Analysing and Evaluating Flood Risk Governance in Belgium. Dealing with Flood Risks in an Urbanised and Institutionally Complex Country' (2016). 
to be realised, which may change the distribution of burdens and benefits. Studies of these shifts in strategies and their distributional effects do not exist.

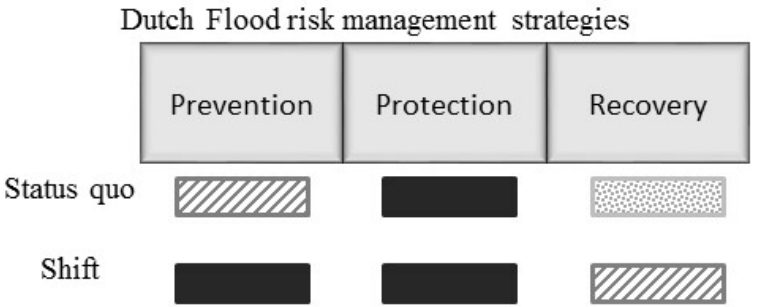

Flemish Flood risk management strategies

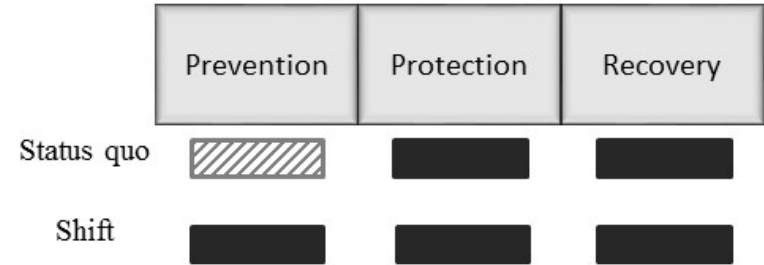

French Flood risk management strategies

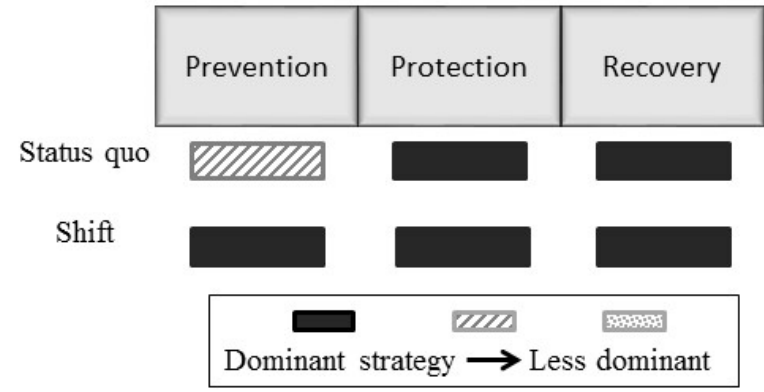

Figure 1: shifts of dominant FRM strategies ${ }^{10}$

Flanders, France and the Netherlands share not only a shift in strategy but also two river basins: those of the Scheldt and Meuse. They thus offer an ideal object to study the legal effects caused by these shifts in strategy, including changes in their compensation regimes."

10 The author adapted the figures, created in the STAR-FLOOD project by Kaufmann and others; Mees and others; Larrue and others (see supra n. 9).

11 The choice for the Flemish region instead of Belgium can be explained by the separation of powers between the state and the regional levels. Flood risk management is a regional task in Belgium, whereas it is national task in both France and the Netherlands. 
Therefore, section 4 addresses the question, 'Are burdens equally distributed by compensation regimes in FRM strategies in Flanders, France and the Netherlands? If that is not the case, what is the cause of the unequal distribution?'

Section 2 then reviews the underlying principles for the equal distribution of burdens in these countries and section 3 discusses how these principles are applied in the three countries?

\section{Distributional effects within the legal framework}

\subsection{Distributional effects}

'Distribution' is the way in which an available supply of something is shared among people or spread over an area. The subject of the distribution varies in each discipline and in each research. Tax law scholarship investigates the distribution of effects on income; climate change scholarship assessed the distribution of effects of climate change on various countries; and ecological scholarship investigates the distribution of concrete species. ${ }^{12}$ In line with the subject of this research, the concept 'distributional effects' is redefined as 'the positive and negative consequences of governmental actions in the field of FRM for individuals and firms'. Economic studies show that legal rules can affect the income distribution. ${ }^{13}$ Translated to a legal formulation, legitimate rules, or - more generally speaking - governmental action can affect the distribution of rights, obligations and risks. ${ }^{14}$ An action that benefits the society as a whole - positive consequences - can also cause adverse effects to a small group of citizens or firms - negative consequences. In other words, legal rules can affect citizens' individual rights.

Various studies have assessed distributional effects of FRM . In order to assess whether flood risk reduction is efficient, economists take into account not only the damage resulting from flooding, e.g. construction of commercial buildings, plumbing repair, and wholesale of furniture, but also the financial

12 See e.g. S. Shavell, Foundations of Economic Analysis of Law (The Belknap Press of Harvard University Press 2004); R.A. Posner, Economic Analysis of Law (7th edn, Aspen Publishers 2007); R. Few, 'Flooding, Vulnerability and Coping Strategies: Local Responses to a Global Threat' (2003) 3 Progress in Development Studies 43; J. Paavola \& W.N. Adger, 'Fair Adaptation to Climate Change' (2006) 56 Ecological Economics 594; J. Soberón \& M. Nakamura, 'Niches and Distributional Areas: Concepts, Methods and Assumptions' (2009) 106 Proceedings of the National Academy of Sciences of the United States of America 19644.

13 Shavell, supra n. 12.

14 B. de Vries, 'Sustainable Uncertainty: Normalising the Ecological State of Exception' (2014) 24 WaterLaw 92; L. Francot-Timmermans \& U. de Vries, 'Eyes Wide Shut: On Risk, Rule of Law and Precaution' (2013) 26 Ratio Juris 282; P.P.J. Driessen \& H.F.M.W. van Rijswick, 'Normative Aspects of Climate Adaptation Policy' (2011) 2 Climate Law 1. 
burdens of financing FRM measures, in most cases borne by the tax payer. The benefits, such as the employment the repair creates, are also taken into account. ${ }^{15}$ Some studies include the avoided damages among the benefits. ${ }^{16}$ Because of all these different definitions and approaches, it is important to define the concepts used.

The focus of economic studies is usually on 'efficiency, ${ }^{17}$ which differs from this paper's approach, which is a legal assessment of the distributional effects of FRM. The burdens are therefore defined differently too. Although this legal assessment also considers loss that can be evaluated in money, the focus is on the infringements of rights. Preventive FRM can cause disproportionally large burdens to a small group of citizens or firms. In order to prevent floods, measures that touch upon property rights are necessary. To give an example: water storage areas can impose restrictions on the uses of privately owned land, ${ }^{18}$ which can lead to devaluation or deprivation of property or a loss of income. These burdens are considered the adverse effects of preventive FRM. Therefore, the scope of the distributional effects assessed in this paper is further limited to 'the negative consequences of lawful FRM that infringe possessions or property rights.'

In order to create equitable and legitimate FRM, the burdens should be spread over the community as fair as possible. Every citizen of a state benefits from actions for the common good and therefore also bears some burdens connected to the benefits mentioned. In the case that these burdens are not proportional, compensation is necessary to equally divide the benefits and burdens among the society. This distribution of burdens and benefits fits into the principles of equity and legitimacy. ${ }^{19}$ For equity, fair burden sharing is important. Burdens are spread more equally in case when disproportional burdens are (partially) compensated. ${ }^{20}$ From a social science point of view, outcome

15 E. Penning-Rowsell \& J. Pardoe, 'Who Benefits and Who Loses from Flood Risk Reduction?' (2012) 30 Environment and Planning C: Government and Policy 448.

16 See supra n. 1.

17 L. Kaplow \& S. Shavell, 'Why the Legal System Is Less Efficient than the Income Tax in Redistributing Income' (1994) 23 The Journal of Legal Studies 1 667; C.W. Sanchirico, 'Taxes Versus Legal Rules as Instruments for Equity: A More Equitable View' (2000) 29 The Journal of Legal Studies 797; R. Cooter \& T. Ulen, Law \& Economics (6th edn, Pearson Education 2012).

18 W. van Doorn-Hoekveld, 'Compensation in Flood Risk Management with a Focus on Shifts in Compensation Regimes Regarding Prevention, Mitigation and Disaster Management' 216; W.J. van Doorn-Hoekveld \& F.A.G. Groothuijse, 'Analysis of the Strengths and Weaknesses of Dutch Water Storage Areas as a Legal Instrument for Flood-Risk Prevention' (2017) 14 Journal for Environmental \& Planning Law 76.

19 M. Alexander, S. Priest \& H. Mees, 'A Framework for Evaluating Flood Risk Governance' (2016) 64 Environmental Science a Policy 38.

20 Driessen \& Van Rijswick; D.S.G. Thomas \& C. Twyman, 'Equity and Justice in Climate Change Adaptation amongst Natural-Resource-Dependent Societies' (2005) 15 Global Environmental Change 115; W. van Doorn-Hoekveld and others, 'Distributional Effects of Flood Risk Management - a Cross-Country Comparison of Preflood Compensation' (2016) 21 Ecology and Society 26. 
equity regarding climate change adaptation refers to 'identifying who gains and who loses from any impact or adaptation policy decision. ${ }^{21}$ Translated to FRM, we have to assess who gains and who loses from the impact of FRM measures. In order to achieve equitable FRM, the adverse effects must be mitigated to some extent. Also legitimacy plays a role. Van Buuren et al. define legitimacy as 'it is a government's duty to use powers only for the reasons for which they are granted, to avoid the abuse of power, and to create a fair, reasonable, and proportionate balance of public and private interests. ${ }^{22}$ When the gains, burdens and the possible compensation thereof are taken into account in decisionmaking, the decision-making is considered to be fair and proportional. ${ }^{23}$

\subsection{Distributional effects of FRM}

FRM is an eminent example of a policy-field that distributes burdens and benefits. As flood risks are distributed unequally among society, people in risk areas benefit more from FRM than people in a relatively 'riskfree' area. ${ }^{24}$ These factors can also influence the burdens these individuals should bear. However, one can state that the whole society benefits to some extent from the protection against flooding. For example, the economic heart of the Netherlands is the most low-lying part and if it floods, it would have major economic consequences for other parts of the country as well. Therefore, people in other parts of the country also benefit from protecting that part of the country. ${ }^{25}$

The losses or adverse consequences of preventive FRM are limited to the adverse effects on citizens or firms resulting from the government's lawful actions. These consequences include a loss of income, a devaluation of property, or in the most serious case, deprivation of property or expropriation.

21 W.N. Adger, N.W. Arnell \& E.L. Tompkins, 'Successful Adaptation to Climate Change across Scales' (2005) 15 Global Environmental Change 77, 83.

22 A. Van Buuren and others, 'Toward Legitimate Governance Strategies for Climate Adaptation in the Netherlands: Combining Insights from a Legal, Planning, and Network Perspective' (2014) 14 Regional Environmental Change 1021, 1023.

23 Of course, besides other criteria for proportional decision-making.

24 C. Johnson, E.C. Penning-Rowsell \& D. Parker, 'Natural and Imposed Injustices: The Challenges in Implementing “Fair” Flood Risk Management in Engeland' (2007) 173 The Geographical Journal 374. M. Petterson et al, 'How legitimate is flood risk governance in Europe? Insights from intra-country assessments' [under review].

25 An increase of employment and similar gains are not addressed in this approach, because it does not influence the legal distribution of consequences. 


\subsection{Mitigation of distributional effects}

In order to reduce the harmful distributional effects of FRM, the studied countries apply compensation regimes Section 4 scrutinises the relevant compensation regimes. In general, compensation is paid by the competent actor, mostly an authority, that causes the damage. ${ }^{26}$ Taxes provide the financial resources for these authorities, and these are therefore born by the society. Conditions for property rights infringement must be laid down in law (art. 17 CFREU and 1 FP ECHR) and in case of deprivation, compensation must be granted. Domestic compensation regimes of Member States provide compensation in specific cases, with criteria laid down in law. These mitigate the adverse effects . Two relevant compensation regimes are of supranational relevance. The French principle égalité devant les charges publiques (hereafter égalité principle) is present in the three countries. However, it forms a safety net for all countries party to the ECHR in different manifestations and Article 1 First Protocol of the ECHR.

\subsection{Mitigation through the principle égalité devant les charges publiques'}

Legal scholars discuss distributional effects mostly in the field of no-fault liability. Liability regimes for lawfully caused harm are established in most Member States, and Article 1 First Protocol ECHR also provides a safety net for the property rights infringements, justified by the public interest. Apart from Article 1 First Protocol, an important principle of no-fault liability is the French principle of equality before public burdens (égalité devant les charges publiques, hereafter: égalité principle). The principle came into existence in the wake of the French Revolution. ${ }^{27}$ In the first Constitution (1789) after the Revolution, the Déclaration des Droits de l'Homme et du Citoyen, declared some fundamental rights, including the right to property. Another crucial aspect of the Déclaration was the equality of all French citizens. ${ }^{28}$ Although it is considered that the abovementioned Déclaration formed the basis of the égalite principle, the French Council of State introduced the principle as such in its case law as one of the principes généraux du droit. ${ }^{29}$ Since a decision of the Constitutional

Van Doorn-Hoekveld and others, see supra n. 20.

M.K.G. Tjepkema, Nadeelcompensatie Op Basis van Het Égalitébeginsel: Een Onderzoek Naar National, Frans En Europees Recht (Wolters Kluwer 2010) 62.

As a reaction on the Ancien Régime, which can be characterized by inequality.

Which are hierarchical placed under the Constitution, international and European law, and formal legislation, but above other governmental acts. J.-B. Auby \& L. Cluzel-Métayer, 'Administrative Law in France', in: J.G.H. Seerden (ed.), Administrative Law of the European Union, its Member States and the United States (3rd edn, Intersentia 2012) 72. The first decision in which the principle is explicitly mentioned is CE 2 June 1944, rec. 159 (SieurFays). 
Council, the égalité principle has been given also constitutional value. ${ }^{30}$ Belgium and the Netherlands have adopted a derivative form of this principle..$^{11}$

The main question regarding the application of the égalité principle is, 'Has the harm or disruption gone beyond that which an ordinary citizen must accept in the ordinary course of events?'32 This leads us to the principle's essence, that all citizens benefit to some extent from actions in the public interest and therefore must bear some adverse effects of these actions as well. No one, however, must bear disproportionately large burdens caused by actions for the common good. Thus, the state must compensate for any disproportionately large burdens based on the égalité principle. How the proportionality of burdens is assessed depends from case to case.

\subsection{Mitigation through Article 1 First Protocol European Convention on Human Rights (ECHR)}

The requirements of the égalité principle are also found in Article 1 First Protocol ECHR. In 1949, while drafting the ECHR, the United Kingdom and Sweden were large opponents of introducing a right to the protection of property in the ECHR. Their fear consisted mainly by the possible frustration of property rights during the post-war reconstruction. The text of the article addressed this fear by the inclusion of the possibility that the state may infringe on property rights for the public interest.

The text of the Article 1 is as follows:

'Every natural or legal person is entitled to the peaceful enjoyment of his possessions. No one shall be deprived of his possessions except in the public interest and subject to the conditions provided for by law and by the general principles of international law.

The preceding provisions shall not, however, in any way impair the right of a state to enforce such laws at it deems necessary to control the use of property in accordance with the general interest or to secure the payment of taxes or other contributions or penalties.'

The scope of 'possessions' is very broad. Among other things, it includes movable or immovable property, tangible or intangible interests, such as shares, patents, an arbitration award, a landlord's entitlement to rent, the economic interests connected with the management of a business, the right to exercise a profession, and a legitimate expectation that a certain state of affairs will apply. ${ }^{33}$

30 CC 4 July 1989, ECLI:FR:CC:1989:89.254.DC. See also CC 11 February 2011, No. 2010-99;

CC 19 September 2014, No. 2014-417.

$31 \quad$ See supra n. 27; Doorn Hoekveld, supra n. 18, p. 228.

32 D. Fairgrieve, State Liability in Tort (Oxford University Press 2003) 148; Cour Administrative d'Appel Paris 25 May 1999 Felmy, CAA Nantes 22 July 1999, Hébert.

33 M. Carss-Frisk, The Right to Property. Human Rights Handbooks No. 4 (Council of Europe 2001). 
A restriction is that it protects only existing property, and not future property, e.g. by inheritance.

Three rules can be distinguished from the text of Article 1.

1. The principle of peaceful enjoyment of possessions $\left(1^{\text {st }}\right.$ paragraph $)$

2. Deprivation of possession is possible under specific circumstances

( $1^{\text {st }}$ paragraph)

3. Control of use of possession is possible under specific circumstances $\left(2^{\text {nd }}\right.$ paragraph)

There is deprivation of possession when there is a formal expropriation or a transfer of ownership.

When an interference with property is determined - both deprivation and regulation - the next question is whether the interference is justified by the state. A justification is that the interference must serve a legitimate objective in the public or general interest ${ }^{34}$ and the interference is proportionate. There must be a fair balance between the community's general interests and the protection of the individual's fundamental rights. ${ }^{35}$ This balance does not exists when the burdened party bears an individual and excessive burden.

Another important aspect of Article 1 First Protocol ECHR is the requirement of legal certainty or legality. That is, deprivation of possession must be 'subject to the conditions provided for by law'. This sentence 'essentially refers back to domestic law. However, the domestic law must itself be in conformity with the Convention, including the general principles expressed or implied there in'. ${ }^{36}$ The presence of a fair and proper procedure and an appropriate authority that carries out the measures are relevant.

The essence of the article is similar to that of the égalité principle, in that the burden may not be excessive.

\section{Flood related compensation regimes}

There are some generalities of dominant strategies in Flanders, France and the Netherlands. In all three, the protection strategy is most dominant. However, in Flanders and France, the recovery strategy - with a focus on insurance systems - is also quite pronounced, contrary to the Netherlands, where this strategy rarely has developed. All three countries tend to shift to the prevention strategy, in accordance to the FD, which demands integrated FRM.

An example of measures within the prevention strategy are restrictions of land use or the prohibition to build in a - flood prone - area. The protection

\footnotetext{
James v. the United Kingdom, no. 8793/79, 『46, ECHR 1986.

Sporrong and Lönnroth v. Sweden, no. 7151/75; 7152/75, \73, ECHR 1982.

Winterwerp v. the Netherlands, no. 6301/73, \45, ECHR 1979.
} 
strategy is divisible into traditional measures and new measures. Traditional protection measures are related to dikes and other 'hard' flood defence structures, whereas new protection measures include the creation of water storage areas. For this paper, recovery does not include measures, but the compensation of loss caused by a flood. This regards only individuals' actual losses, and not the measures necessary to return to normal circumstances.

Figure 1 shows the current dominant strategies and the shift of dominance. ${ }^{37}$ In all three countries, the shift towards the prevention strategy shows its importance. Policy aims at a more integrated FRM in which prevention has an eminent role. Recovery is also dominant in Flanders and France, because the insurance schemes of those countries are very elaborate. A shift of the dominance of those schemes is not expected. Even though the Dutch are not actually preparing to develop a recovery scheme, recovery is more and more a theme of discussion in the Netherlands, and therefore in the figure it is visualised as a 'shift'. ${ }^{8}$

\subsection{The Netherlands}

The Netherlands is famous for its water management. Already in the Middle Ages, the necessity to protect land against water was known and led to the organisation of water management through regional water authorities, which still exists now. ${ }^{39}$ The western part of the country, its economic heart, lies mostly below sea level. The sea and the rivers cause the main flood risks. ${ }^{40}$

The flood protection strategy has been the dominant strategy. This is visible in the way FRM is framed and regulated. The Water Act includes safety standards and most resources are reserved for measures carried out in this strategy, e.g. by the Flood Protection Programme. ${ }^{41}$ Measures, such as a dike relocation, strengthening, and heightening, can infringe property rights and lead to devaluation or deprivation of property. Loss of income is not found frequently in this strategy. The cause of the damage lies in the decision to strengthen the dike (project plan) or an obligation to tolerate work carried out on property of an individual. ${ }^{42}$ The Water Act provides for compensation based on the égalité

37 The status quo is the situation in 2017. The shift has started some years, or even decades, ago, but is still in process.

38 M. Gralepois and others, 'Is Flood Defense Changing in Nature? Shifts in the Flood Defense Strategy in Six European Countries' (2016) 21 Ecology and Society 37; Kaufmann and others; Mees and others; Larrue and others; W.J. van Doorn-Hoekveld, 'Transboundary Flood Risk Management. Compatibilities of the Legal Systems of Flood Risk Management in the Netherlands, Flanders and France' (2017) 26 European Energy andEnvironmental Law Review 81.

39 H.J.M. Havekes, 'Functioneel Decentraal Waterbestuur: Borging, Bescherming En Beweging' (Utrecht 2009) 13.

40 Kaufmann and others, supra n. 9; Van Doorn-Hoekveld, supra n. 18.

$4^{1}$ The Flood Protection Programme is a fund which finances protection measures: Van DoornHoekveld, supra n. 38 .

$4^{2}$ Article 5.4 and 5.25 Water Act. 
principle, which is not full compensation in most cases. In case the state needs the property for the public interest or imposes an obligation to tolerate on the landowner, and consequently the land has become useless for its owner, expropriation can be necessary. In case of expropriation, the state grants full compensation based on the Expropriation Act. A quite different type of measure is the creation of water storage areas. In the case of high water discharges of rivers, these areas, designated in a water plan (ledger) as well as in a spatial zoning plan, will temporarily store water. ${ }^{43}$ Private parties may use the land designated as water storage area for economic or private activities in times it is not needed for water storage . In most cases, it is used as farmland. The use of this land, however, is not free from restrictions. Regional water authorities may impose use restrictions, which can cause devaluation of the land, as well as a loss of income.

The compensation of loss, caused by the creation of a water storage area is regulated in the Spatial Planning Act and the Water Act. Because of the different possibilities to claim compensation, it is a confusing system. ${ }^{44}$ Both compensation regimes are based on the égalité principle but may lead to different outcomes. The prevention strategy can count on an increased interest, but is not developed much yet. Measures within this strategy are the introduction of risk zoning in spatial plans connected to restrictions of land use. The municipality or province are competent authorities for carrying out these kind of measures. In this case, the compensation regime of the Spatial Planning Act is applicable (see below).

The water manager has one instrument that can influence spatial planning: the Water Assessment. This is a piece of advice to the municipality about water related issues in spatial zoning plans and the municipality is not bound to follow this advice. ${ }^{45}$

The regulation for damage caused by lawful acts in the field of water management of the Water Act has a broad scope:

'Any person who suffers or will suffer damage as a consequence of the lawful exercise of a water management duty or competence shall, at his request, be awarded compensation by the administrative authority concerned where such damage should not within all fairness remain for his account and where compensation is not or not sufficiently otherwise guaranteed. ${ }^{46}$

The Explanatory Memorandum and case law make clear that the main criteria of the égalite principle apply: the burden should be abnormal and special in order to award damages. Burdens should be spread fairly, and thus not only

See for an elaboration of the instrument water storage areas Van Doorn-Hoekveld \& Groothuijse, supra n. 18, p. 76 .

Doorn-Groothuijse, supra n. 18.

See supra n. 38.

Article 7.14 Water Act. 
the burdens of governmental action but also its benefits are considered. All Dutch inhabitants benefit from protection against floods, so it is fair that all inhabitants should also bear some of the connected disadvantages. The égalité principle considers this as a normal social development everyone should take into account, also known as the normal social risk. ${ }^{47}$ The Council of State explained this risk as: 'citizens should take into account a normal social development even though there was no view of the extent to which, the place where and the time at which this development would manifest itself. ${ }^{48}$ The abnormal burden and the special burden are two distinct criteria of the égalité principle. In order to suffer an abnormal burden, the loss must be disproportionally large. The abnormal burden is mostly set as a threshold ${ }^{49}$ that differs widely and is not always extensively motivated in case law. For coastal defence works, a threshold of $5 \%$ of the property value was considered fair. ${ }^{50}$ The special burden demands that the burdened party is burdened more than others that are in a similar situation..$^{51}$

The regime of the Spatial Planning Act is more concise. There, the abnormal burden has been specified with a threshold: at least $2 \%$ of the value of property or at least $2 \%$ of the average yearly income that will remain for the damaged party. ${ }^{52}$ In case law, there is no attention for the special burden. Case law considers that in case the loss is considered abnormal, it is special as well. ${ }^{53}$

The National Water Plan of 2009 introduced, the multi-layered safety approach, whose aim is to create a more integrated approach to reduce flood risks. Three layers can be distinguished: prevention (which corresponds to protection

47 Van Doorn-Hoekveld see supra n. 18, p. 228.

48 ABRvS 17 April 2013, ECLI:NL:RVS:2013:BZ7718, translated by B. van den Broek, 'Compensation of Damages within a Systematic Approach to Large-Scale Water and Infrastructure Projects' (2015) 24 Journal of Water Law 266, 268.

49 E.g. for devaluation of property caused by coastal defence works, the abnormal burden is considered to be an amount of $5 \%$ of the value of the property, see: ABRvS 9 April 2014, ECLI:NL:RVS:2014:1198.

50 ABRvS 9 April 2014, ECLI:NL:RVS:2014:1198; also loss with a value of 2,22\% of the value of the property was not considered to be abnormal (ABRvS 3 July 2013, ECLI:NL:RVS:2013:164) and loss with a value of $1 \%$ of the yearly turnover was not considered to be abnormal (ABRvS 22 May 2013, ECLI:NL:RVS:2013:CAo631).

51 ABRvS 19 February 2014, ECLI:NL:RVS:2014:572.

52 The threshold is only applicable for indirect planning blight. For direct planning blight a threshold can be applied, but it is not mandatory. This threshold is a minimum. The specific circumstances of the case may demand a higher threshold. Indirect planning blight is loss caused by value-reducing developments of the surrounding of the property instead of adverse effects of spatial planning, e.g. restrictions of use, on the property itself (direct planning blight).

53 B.J. Ettekoven, Wat Is Normaal? Van Planschade Naar Nadeelcompensatie (Vossiuspers UvA 2011) 17; B.J. van Ettekoven and others, 'Overheidsaansprakelijkheid Anno 2013: De Stand van de Rechtsontwikkeling’ [2013] Overheid en Aansprakelijkheid 49. 
in the FD), spatial planning (which corresponds to prevention) and evacuation (which corresponds to emergency response). ${ }^{54}$

A shift from protection towards prevention, therefore, leads to a shift of compensation regimes as well. For measures in the protection strategy, the Water Act is the applicable regime in almost all cases. For spatial planning measures, the Spatial Planning Act regime is more appropriate. This leads to a shift of also the competent authority. ${ }^{55}$ Authorities can conclude agreements on the question which authority needs to pay the compensation. Nevertheless, the shift in responsibilities and fear of liability can hamper the development of the prevention strategy. Also from the perspective of the burdened party, it is confusing that the authority competent for water management is not in all cases the authority that is competent for compensating the damage. In case the Spatial Planning Act is applicable, the competent authority is the municipality, and the amount of compensation paid may differ. ${ }^{56}$

The Netherlands does not have an explicit ex post compensation regime. The Calamities Compensation Act is a safety net to compensate flood damage after a flood disaster. The state must formally declare a flood to be a national disaster for the act to come into action. ${ }^{57}$ The activation of the Act comes by Royal Decree, which happened five times since 1998. The details of every application are laid down by Ministerial orders. The Act grants only partial compensation to burdened parties, and generally means providing the funding. Mandatory flood insurance is not available, even though one pilot is currently running. ${ }^{58}$ This limited focus on ex post compensation can be explained by geographical characteristics of the country; if a major flood disaster occurs the consequences will be devastating and damage will be enormous. Insurance companies declared flood damages uninsurable in the past. Furthermore, as stated above, the focus lies strongly on prevention and protection.

\subsection{Flanders}

In Flanders, the shift from protection towards prevention has commenced with the Decree on Integrated Water Policy (henceforth DIWP) in

\section{between brackets.}

55 See for an elaboration of the different regimes: Van Doorn-Hoekveld, supra n. 18 and Van Doorn-Hoekveld and others, supra n. 20.

56 Van Doorn-Hoekveld; Van Doorn-Hoekveld \& Groothuijse, supra n. 18.

57 A disaster is 'a major accident or other event in which the life and health of many people, the environment, or major material interests are harmed seriously or are at risk and which require a coordinated deployment of services and organizations from different disciplines to eliminate the threat or reduce the harmful effects' according to Article 1 Security Regions Act (Governmental Gazette, 1 April 2010, No 145).

58 C. Suykens and others, 'Dealing with Flood Damages: Will Prevention, Mitigation, and Ex Post Compensation Provide for a Resilient Triangle?' [2016] Ecology and Society. 
2003. The reform of the DIWP in 2013 strengthened the prevention strategy even more. Preventive measures are, amongst other measures, the creation of signal areas, which are undeveloped areas where the prospect of development may conflict with the interests of the water system, such as storage capacity. In signal areas, the Flemish Government can decide about the next step trajectory, which determines which actions must be taken and which instruments should be used. This depends on whether the area is compatible with the necessary water storage capacity. The state can impose restrictions of land use, or rezoning can be necessary. ${ }^{59}$

An important instrument in the next step trajectory of signal areas is the Water Test, ${ }^{60}$ which is used not only in signal areas, but also for other spatial developments in order to guarantee the integration of water interest in spatial planning. Therefore, it is an important instrument in the prevention strategy. ${ }^{61}$ When the Water Test indicates that the desired development would lead to harmful effects on the water system, it implies a need for alternatives to prevent or reduce the harmful effect (first stage), to repair or compensate the harmful effect (second stage) or to refuse a permit (third stage), the latter being an ultimum remedium..$^{62}$ The authority competent for assessing the Water Test has large discretionary power. ${ }^{63}$

A negative Water Test - restrictions on land use or a refusal of the permit does not allow compensation for the owner per se. It is not necessary to compensate all loss resulting from actions to realise objectives for the public interest. This is in accordance with Article 544 Belgian Civil Code, Article 16 Belgian Constitution and 1 First Protocol ECHR. ${ }^{64}$ Different authors contest this vision. ${ }^{65}$ For the consequences of a negative Water Test, no compensation regulation exists.

However, in some cases, the competent authority can lay down the consequences of the negative Water Test in spatial plans, which can have negative effects on the property value or create a loss of income. For this type of loss, the Spatial Planning Code (henceforth: SPC) is applicable. The code proves a stringent compensation scheme . Rezoning leads, in specific cases, to compen-

59 P. De Smedt, 'Towards a New Policy for Climate Adaptive Water Management in Flanders: The Concept of Signal Areas' (2014) 10 Utrecht Law Review 107.

6o Article 8 DIWP.

61 J. Toury \& M. Denys, 'Vernieuwde Watertoets' [2012] Nieuw Juridisch Weekblad 82; De Smedt, supra n. 59.

62 De Smedt, supra n. 59, p. 114 .

63 Court of Cassation 8 March 2013, No. C.12.0333.N.

64 Also the Constitutional Court (9 February 2005, judgement 32/2005), Court of Cassation (16 March 1990) and the Council of State (16 June 1981, judgement 21.269) ruled that restrictions may be imposed without compensation.

65 Toury \& Denys, supra n. 61, p. 88; P. De Smedt, 'De Watertoets Getoetst' [2004] Nieuw Juridisch Weekblad 902. 
sation for the owner. Compensation is awarded only when, based on a spatial implementation plan, a plot is no longer eligible for a permit to build it or allot it when it had that possibility before the spatial implementation plan came into effect. $^{66}$ This means that only developments that touch the plot of an owner can establish grounds for the compensation of planning blight. ${ }^{67}$ The burdened parties receive a maximum of $80 \%$ of the devaluation. ${ }^{68}$

When the Water Test does not provide the necessary water storage capacity in flood prone areas, the competent authority can also establish easements in the public interest. ${ }^{6}$ These can impose restrictions on the right of property. The compensation to the owner, usufructuary or user of the land in question of the resulting devaluation of property is arranged in Article 2.1.4 of the Decree. The height of the compensation is determined based on the decrease in the market value of the property. The compensation for loss of value of land that belongs to the user is determined based on the actual reduction of the use of the property. In this case, the competent authority compensated the actual loss and no extra criteria, such as the abnormal and special burden, are applied.

Within the protection strategy, the creation or strengthening of flood defence structure and the creation of flood control areas can lead to dispossession of property and the activation of flood zones can lead to a loss of income. For measures carried out in the protection strategy, expropriation rules apply. For spatial planning measures, the rules regarding the compensation of planning blight apply. The Decree of Integrated Water Management includes different compensation instruments.

For flood defence structures, the Dike Decree is relevant. ${ }^{70}$ The authority can expropriate real estate that is needed to carry out flood defence works (Article 7), or, when the works lead to devaluation, it can compensate the devaluation (Article 8$).{ }^{71}$ In addition, the burdened owner can oblige the authority to buy its property (Article 9).

Water storage areas are designated in water plans as well as spatial plans. The DIWP and the UPC provide compensation regulations. The burdened party has to choose which route for the compensation to take. ${ }^{72}$ Another possible

66 Article 2.6.1 SPC.

67 This means that the compensation is only granted in case the measure affects the property directly. The Dutch system, to the contrary, does also compensate indirect planning blight: when a development near a specific plot leads to devaluation, it can also lead to - partial compensation of that indirect planning blight.

68 Article 2.6.2 \2 SPC.

69 Article 2.1.3 Decree on Rural Land Use Planning (Decreet betreffende de landinrichting) (Belgian Official Journal 22 August 2014, p. 63616).

70 Belgian Official Journal 1 June 1996, p. 15044

71 An amount of $20 \%$ of the reference value of the property should be borne by the burdened party.

72 Van Doorn-Hoekveld and others, supra n. 20. 
cause of loss is the activation of water storage areas (Article 2 (44 and 44bis) DIWP). In that case, owners of plots that are used for agricultural or forestry use and that suffer a loss of income caused by the activation can demand compensation based on Article 17『2 DIWP. Compensation of the loss of income is detailed in Article 23 Order on Financial Instruments of Integrated Water Policy (Besluit Financiële Instrumenten Integraal Waterbeleid).

In case the designation of flood zones leads to a remarkable devaluation of property or threatens the viability of the business - more than $20 \%$ of the reference value - or to remarkable loss of income - more than $2 / 3$ of the reference income - the owner can ask the competent authority to buy the plot. ${ }^{73}$

Article 10 and 11 of the Belgian Constitution ${ }^{74}$ or 16 of the Belgian Constitution $^{75}$ include a derivative of the égalité principle. In 2012, the Constitutional Court has broadened the scope of the égalité principle to restrictions of property rights for the public interest in general. ${ }^{76}$ This was a new vision, since the Court of Cassation and the Council of State limited the scope of compensation to deprivation resulting in the restriction of property rights to not automatically lead to compensation. ${ }^{77}$ The case law of the Constitutional Court has consequences for situations in which governmental action in the public interest infringes on property rights in a manner for which no compensation regulation is applicable. ${ }^{78}$ Even though the Court has not applied the principle in the case of negative Water Tests, competent authorities must take into account that burdened parties can appeal to the égalité principle. How the principle relates to adverse effects that do not touch the property itself, but are in the near surroundings and lead to devaluation is not clear yet. ${ }^{79}$

Nuisance (burenhinder) is another Belgian compensation regime, which is codified in Article 544 of the Civil Code. The regime of nuisance can be applied between citizens together or between a citizen and a public authority - neigh-

73 Article 17\$1 DIWP and Article 10 Order on Financial Instruments of Integrated Water Policy.

74 The Court of Cassation holds these articles as the basis of the égalité principle: Article 10: No class distinction exist in the State. Belgians are equal before the law [...]. (equality principle) Article 11: Enjoyment of the rights and freedoms recognised for Belgians must be provided without discrimination [...]. (non-discrimination principle).

75 The Constitutional Court holds Article 16 as the basis for the égalité principle: No one can be deprived of his property, except in the case of expropriation for a public purpose, in the cases and manner established by the law and in return for fair compensation paid beforehand.

76 Constitutional Court 19 April 2012, No 55/2012, rec. B3.1-B3.3.

77 Court of Arbitration 27 March 1996, No 24/96; 12 July 2001, No 97/2001; Council of State 25 Octobre 2001, No 100.286; G. Van Hoorick, 'Over Eigendom, Zijn Omgeving En Het Omgevingsrecht (of Zin En Onzin van de Gelijkheid van de Openbare Lasten)' (2013) 2 Tijdschrift voor Omgevingsrecht en Omgevingsbeleid 182, https://biblio.ugent.be/publication/4193776/file/ 6806016.

78 Van Doorn-Hoekveld and others, supra n. 38.

79 See supra n. 77. 
bours. ${ }^{80}$ This regime institutes a no-fault liability regime that can disrupt the equilibrium between one estate and other estates. ${ }^{81}$ It is necessary that the burdened party proves that its neighbour has exceeded the acceptable degree of interference due to a well-defined act of the neighbour; which can be attributed to the neighbour and, which is only at stake when the defendant is a public authority, the loss is more than the charges one has to bear in the collective interest. The latter is interesting, since the formulation is quite similar to other no-fault liability formulations.

Importantly, for the recovery strategy, an act or decision of an authority is not the cause of loss, but the actual flood is instead. This leads to damage of property. An insurance system, which is governed at federal level, covers compensation of this damage. Until 2007, public funding fully covered ex post compensation, but since then fire insurance has automatically included flood coverage $^{82}$ Fire insurance policies are not mandatory, but $90-95 \%$ of the population does have fire insurance, ${ }^{83}$ which can be explained by the fact that a fire insurance is a condition for obtaining a mortgage. ${ }^{84}$ In 2014, the Regions received the powers of the federal Disaster Fund (Compensatiekas Natuurrampen). For Flanders, the Flemish Disaster Fund (Vlaams Rampenfonds) is the fall-back mechanism for coverage when damage has exceeded the insurers' limits have been exceeded or for compensation of goods that do not fall under the coverage of the insurance. ${ }^{85}$ The insurance premiums differ between flood prone and risk-free areas, which discourage buying and building in flood prone areas. Insurers are not obliged to provide coverage in flood prone areas, and the Disaster Fund will not compensate in these areas. ${ }^{86}$ This is a strong bridging mechanism between the prevention strategy and the recovery strategy. ${ }^{87}$

80 This section deals only with the nuisance between a citizen and a public authority.

81 H. Vuye, 'Fundamentele Regels En Recente Tendensen Inzake Burenhinder', in: M. Debaene \& P. Soens (eds.), Aansprakelijkheidsrecht: Actuele tendensen (De Boeck \& Larcier 2005); I. Durant, 'Belgium', in: K. Oliphant (ed.), The Liability of Public Authorities in Comparitive Perspective (Intersentia 2016).

82 Article 123 Insurance Act of 4 April 2014, Belgian Official Journal 30 April 2014, p. 35487; Cathy Suykens and others, 'Dealing with Flood Damages: Will Prevention, Mitigation, and Ex Post Compensation Provide for a Resilient Triangle?’ (2016) 21 Ecology and Society 1.

83 P. Colle, 'De Wet van 17 September 2005 Betreffende de Verzekering van Natuurrampen' (2006) 69 Rechtskundig Weekblad 881.

84 Suykens and others, supra n. 58.

85 Ibid.

86 Ibid.

87 H.K. Gilissen and others, 'Bridges over Troubled Waters - An Interdisciplinary Framework for Evaluating the Interconnectedness Withing Fragmented Flood Risk Management Systems' (2016) 25 Journal of Water Law 12. 


\subsection{France}

France designates areas that can potentially flood, in the natural state of a watercourse as flood areas. According to Article L 125-2 of the Environment Code, 'citizens have a right to information on the major risks to which they are subject, which applies to technological risks and to foreseeable natural risks.'

Therefore, the flood zones are included in atlases that are publicly available in town halls. The local risk prevention plan (PPR) inform citizens of the flood risks (maximum height, frequency and duration of the floods). ${ }^{88}$

Apart from the flood zone atlas, the flood risk prevention plans (PPRi) identify zones. In 'danger' zones where the risk is high, no building permits for new constructions can be issued. In medium-risk 'precaution' zones, the building permit is subject to conditions, and otherwise the building permit is subject to the local zoning plans (PLU) rules.

An approved PPRI is, with all its indications and regulations, a public utility easement (servitude d'utilité publique).

Administrative easements encumber a property and are established for a general interest purpose.

A burdened party cannot claim compensation caused by public utility easements, unless the applicable legislation provides for it. ${ }^{89}$ In most cases, it grants no compensation to properties impaired by a land use plan, because, vice versa, the government does not recover part of the private benefit generated by public works. However, the courts have made an exemption for power poles. In the case that poles are built at the property, compensation is granted. ${ }^{90}$ This may directly infringe on property rights, just as the erection of a dike.

Public utility easements may lead to certain prohibitions or limitations on owners' exercise of their right to construct, and more generally to occupy or use the soil, or to support the execution of works or the installation of certain works. More rarely, they can impose certain obligations to be borne by the

88 Apart from the responsibility of the authority to establish such plans including these zones, burdened parties do have their own responsibility. In a case burdened parties have bought a parcel to build two houses. After a storm in 1999 the prefect had published different maps which showed the maximum water levels. The community did not, even though it should have, included a unbuildable zone in its land use plan. The parties who claimed to be burdened because the community did not have acted according to its responsibility was remonstrated that 'by neglecting to ensure for themselves the safety of the parcels located at the edge of the beach, which they proposed to acquire for the purpose of constructing two houses there, only a few years after the occurrence of this storm, the effects of which had been widely covered by the media, the burdened parties have committed an imprudence which justifies leaving them to bear a share of responsibility'. (CAA Bordeaux, 14 June 2016, N 14BXo2616, rec. 12).

89 J. Gordley, Foundation of Private Law. Property, Tort, Contract, Unjust Enrichment (Oxford University Press 2006) 96.

90 Cass. Civ. 6 January 1930, S1930.1.337 and Cass. Req. 3 June 1935, S1935.1.246. 
owners (maintenance or repair work). For temporary water storage areas, based on Article L211-12 Environmental Code, the authority will compensate the direct, material and certain loss (art. L211-12 VIII), when an amicable agreement is not possible. Furthermore, the real damage to crops, livestock, motorised land vehicles and buildings caused by over-flooding due to temporary retention will be compensated (art. L211-12 IX). The institution which has requested the temporary water storage in the specific area must bear the compensation.

Another easement is the urban planning easement (servitude d'urbanisme), which is subject to the principle of non-compensation provided for in Article L. 105-1 of the Urban Planning Code. The article provides for some exemptions of this non-compensation principle as well, such as when the easement leads to an infringement of acquired rights or a modification to the previous state of the premises determining direct, material and certain damage. These strict requirements have much in common with the égalité principle, in that the burden must also be special and abnormal, although one may argue that Article L. 1051 UPC provides a restriction of the égalite principle, since the criteria of the égalité principle are easier to fulfil in other policy fields than the criteria of L. 105-1 UPC..$^{11}$

Preventive measures such as the inclusion of building prohibitions or restrictions of land use in spatial plans are public easements. Only in cases where the easement leads to material, direct and certain prejudice, compensation is granted.

In 2016, the Council of State provided the first positive application of the principle, introduced in the Bitouzet case..$^{92}$ The Bitouzet ruling adapted the principle of non-compensation of Article L. 105-1 UPC in the sense that the exemptions fulfil the 'test' of Article 1 First Protocol ECHR. Compensation only is in place for a special and exorbitant charge, which is disproportionate to the general interest objective. ${ }^{93}$ In the 2016 case, the Council of State stated that 'these provisions [of the Urban Planning Code, author] establish a special regime of exclusive compensation, which is not an application of the ordinary law of the no-fault liability of the administration for breach of the égalité principle.' Nevertheless, these provisions do not prevent the owner whose property is

CE 6 June 2012, ECLI:FR:CESSR:2012:329123.20120606. In this decision, the Conceil d'État assessed the requirements of Article L. 160-5 Urban Planning Code (currently renumbered: L. 105-1) together with the requirements of the égalité principle with regard to the rejection of a building permit in a unbuildable zone. The Conseil d'État stated that if the loss results exclusively from the classification of the land use plan, the burdened parties are not entitled to seek for compensation. Before Article L. 105-1 Urban Planning Code, the Conseil d'État used the égalité principle for compensation requests based on the classification of planning zones (e.g. CE 11 April 2011, ECLI:FR:CESSR:2011:322956.20110415).

92 CE 29 June 2016, $\mathrm{N}^{\circ}$ 375020, ECLI:FR:CECHR:2016:375020.20160629. In this case the compensation regime of Article L.105-1 (former Article L. 160-5) Urban Planning Code was contested.

93 CE 3 July 1998, rec. p. 288 (Bitouzet). 
subject to an easement from claiming compensation in the case that the burden is special and abnormal and not in proportion to the general interest that imposed the easement. ${ }^{94}$ These criteria, although explicitly disconnected from the égalité principle, resemble the égalité criteria.

Property may be expropriated in case of a foreseeable risk of, among other things, fast-rising floods or marine submersion seriously threatening human life. The state may declare the expropriation when the means of safeguarding and protecting the population prove to be more costly than expropriation (Article L. 561-1 Environmental Code). The normal rules of the Expropriation Act are applicable for the expropriation, ${ }^{95}$ which must be proportionate. It is obligatory to consider first whether other measures to safeguard the population are possible. Thus, in the case of a temporary risk of flooding, e.g. at certain times of the year, the prohibition of camping, caravanning or the establishment of mobile homes on bare land may be sufficient to avoid the exposure to this risk. In addition, requirements may be adopted for agricultural land during such periods. Given its low cost, it must then be preferred to expropriation. If a party acquires property after the publication of a PPR with a zone where it is prohibited to construct, the purchaser has no right to compensation or reduced compensation (art. L. 561-2 Environmental Code).

For the strengthening of flood defence structures and the creation of water storage areas, the instrument of public easements is used. In case of an excessive infringement, expropriation is possible.

In the past, the principle was applied in relation to infrastructural measures, such as the lawful decision to construct a dam. ${ }^{96}$ The égalité principle could have a very broad application in these contexts. The courts, however, have limited the scope by introducing control mechanisms, specifically to restrict the impact of the principle. ${ }^{97}$ The courts have been successful, given the many rejections of compensation claims.

Although not based on the égalité principle, the oldest branch of no-fault liability is loss arising from public works (travail or ouvrage public), such as

94 CE 29 June 2016, N³75020, ECLI:FR:CECHR:2016:375020.20160629, rec. 20 : 'que ces dispositions instituent un régime spécial d'indemnisation exclusif de l'application du régime de droit commun de la responsabilité sans faute de l'administration pour rupture de l'égalité devant les charges publiques.'

95 Preventive measures, such as the abovementioned expropriation, the amicable purchase of land and the amicable purchase of property, used for professional purposes employing fewer than twenty employees, in particular individual, commercial, farming or artisanal enterprises and their taxable land, as well as the measures required to limit access and to prevent any occupation, providing that the land purchased is made unsuitable for building within three years, when these properties have been damaged to the extent of more than half their value and indemnified in application of Article L. 125-2 of the Insurances Code (Art. 561-3 Environmental Code), are financed by the major natural disaster prevention fund.

96 Conseil d'État 24 March 1978, Advenier.

97 See Fairgrieve, supra n. 32, p. 149. 
dams..$^{98}$ In the Entreprise Bec Frères case, ${ }^{99}$ a dam breached following heavy rainfall. Subsequent flooding caused damage to property of the Bec brothers. The Council of State denied that the cause of the breach was a force majeure, ${ }^{100}$ but also that it was an internal defect. Instead, heavy rains had weakened rocks below the dam, which slipped due to an unsuspected crack. Therefore, the Var Départment had to compensate the damage. This means that in case of a force majeure, e.g. floods, lightning or wars, no liability is accepted. Besides this requirement, the burden must also be abnormal and special, as is the case of the égalité principle.

The concept of the general interest is very important in French law, because this justifies many infringements, even without compensation in some cases. ${ }^{101}$

Expropriation for reasons of public utility is an administrative operation by which the state imposes the transfer of the ownership of private immovable property for a purpose of public utility and by means of a just and prior indemnity. ${ }^{102}$ Even though the instrument expropriation has evolved, the principles of a just and prior indemnification are still important. ${ }^{103}$

Amongst other things, France is famous for its ex post compensation scheme, called the Catastrophes Naturelles (CAT-NAT) regime, a public-private partnership that the French Parliament adopted in 1982. Within this regime, in insurance policies for buildings and movable property cover flood risks. ${ }^{104}$ Additional premiums are transferred to the Central Reinsurance Company (CRC), owned by the state. Insurers can purchase reinsurance by the CRC or a private insurer to guarantee their ability to compensate their insured parties in case of a disaster. ${ }^{105}$ The premiums are independent of the flood risks of citizens, but are a fixed rate. ${ }^{106}$ Twelve percent of the premiums are redistributed to the Fund for the Prevention of Major Natural Hazards (also called: Barnier Fund), which finances a large part of projects in the prevention strategy. ${ }^{107}$ The insurance company may amend a reduction of the insured capital if the property lies within an area in which no flood risk prevention plan (PPRi) has been es-

\footnotetext{
98 Ibid 150.

99 Conseil d'État 28 May 1971, Entreprise Bec Frères.

100 Which is together with the fault of the victim an exemption from liability.

101 G.C.A. Henriot, Le Dommage Anormal: Contribution à l'étude d'une responsabilité de structure. (Editions Cujas 1960) 54; P. Dévolvé, Le Principe d'égalité devant les charges publiques (Librairie générale de droit et de jurisprudence 1969) 352.

102 Translation by the author: Y. Gaudemet, Droit Administratif (2oth edn, Lextenso éditions, LGDJ 2012) 561 .

103 Ibid 562.

104 V. Bruggeman, Compensating Catastrophe Victims: A Comparative Law and Economics Approach (Kluwer Law International 2010).

105 Suykens and others, supra n. 58.

106 Article L. 125-2 Insurance Code and Article 1 Decree of 9 March 2009.

107 Article L. 125-2 Insurance Code and Article 1 Decree of 9 March 2009.
} 
tablished. ${ }^{108}$ Furthermore, insurance companies may refuse to cover buildings that are built in an unbuildable zone of a PPRi after the plan was published. ${ }^{109}$ When the property was built before the PPRi came into effect, the insurance company may not refuse to insure the property. The reduction of compensation for areas with no PPRi and the refusal of insurance for building in unbuildable zones should make up the lack of incentives to connect recovery to prevention by the fixed insurance premium. Some authors argue, however, that the latter does not encourage prevention. ${ }^{110}$ In case someone did not comply with the restrictions belonging to the zones imposed by the mayor, the insurance would not compensate loss (art. L. 125-6 Insurance Code).

\section{Comparison and interpretation of the compensation regimes}

The research question consists of two parts: section 4.1 addresses the first part - 'are burdens equally distributed in flood risk management strategies by compensation regimes in Flanders, France and the Netherlands?, which compares the different compensation regimes of the relevant FRM strategies in the studied countries, arranged per FRM strategy. Section 4.2 addresses the second research question: What is the cause of the unequal distribution? This section identifies two causes which lead to an unequal distribution of burdens.

\subsection{Comparison of distribution of burdens}

The FD strives to integrate FRM so that prevention, protection and preparedness play important roles. ${ }^{111}$ Especially prevention and protection can lead to lawfully caused loss and are therefore relevant in this context. The three studied countries have strong foci on protection, but also have developed or are presently developing prevention. ${ }^{112}$ The type of loss caused by these two strategies differs. Specifically, the prevention strategy potentially leads to more damage, since spatial planning measures need more space than traditional flood protection measures. Within the protection strategy, however, an important shift has occurred as well: in all three countries the instrument of water storage

108 Article L. 125-6 Insurance Code; Suykens and others, supra n. 58; Van Doorn-Hoekveld, supra n. 38 .

109 Van Doorn-Hoekveld, supra n. 38.

110 Larrue and others, supra n. 9, p. 137; Y. Yoshida \& M. Banba, 'Flood Disaster Mitigation Measures Through Land Use Management in the UK and France' in Michiko Banba \& Rajib Shaw (eds), Land Use Management in Disaster Risk Reduction: Practice and Cases from a Global Perspective (Springer Japan 2017) $44^{2}$.

111 Article 7(3) Floods Directive.

112 Van Doorn-Hoekveld, supra n. 38. 
areas has been created in the last decades, complementing the traditional dikerelated measures. This instrument has more spatial implications than the traditional measures.

\section{Protection strategy}

Looking at the traditional dike-related measures, at present the countries have similar compensation regimes. For deprivation, which is in most cases a result of traditional dike-related measures, the compensation regime that fits are the general rules of expropriation, which constitutes full compensation of the loss suffered. For Flanders and France, the compensation does not reach any further. The Netherlands, however, has an additional compensation regime for traditional measures. Furthermore, indirect damage on property, i.e. devaluation of property caused by negative developments in the near surroundings of the affected property, is eligible for compensation based on the égalité principle in the Water Act.

Water storage areas are another kind of protection measure for which different compensation regimes exist. In all three countries, the law distinguishes the situation of the designation or creation of the water storage area and the activation or inundation of the area. In France, a storage area can be created through two water plans, the Water Management Plan (SAGE) and the Local Water Management Plan (SDAGE) or through a public easement. For the easements, the Urban Planning Code and Environmental Code provides a stringent compensation regime, which compensates only the direct, material and certain loss. In Flanders and the Netherlands, the situation is quite similar. The designation of Flemish water storage areas takes place in water plans (art. 2 (44 and 44bis) DIWP) as well as in spatial plans (Article 1.1.2(10) UPC). Likewise, in the Netherlands, the water storage area needs to be designated in the ledger and the spatial zoning plan (Article 1.1(1) Water Act). Both countries deal with the same problem. The compensation regime of the water law as well as the spatial planning law are applicable and burdened parties may choose which route they will take to receive compensation The Dutch Water Act provides a theoretical solution, namely a priority rule in which the Spatial Planning Act is overruled. Case law, however, does not follow this priority rule, which leads to the same unclear situation as in Flanders. ${ }^{113}$

For the inundation of water storage areas, all countries have a specific compensation scheme, which seems to lead to full compensation of the loss of income caused by the inundation. 


\section{Prevention strategy}

Prevention measures are incorporated into spatial plans - all countries - and spatial public easements - Flanders and France - and lead to similar causes of loss: restrictions of land use or even prohibitions to build in specific zones. France has the most strict compensation regime for such measures: public easements do not normally lead to compensation when they are undertaken in the public interest. The French Council of State has awarded compensation for urban planning easements in very limited cases. Even though the Council of State made explicitly clear that the compensation regime of Article L. 105-1 UPC is not the same as the general no-fault liability regime of the égalité principle, the criterion of disproportionally large burden was of decisive importance in assessing the compensation demand. The Flemish Spatial Planning Code provides a very detailed compensation regime for spatial planning measures, such as zoning in spatial plans and the designation of signal areas. Even though it is not easy to receive compensation, the code clarifies under which circumstances one can except to get a certain amount of compensation. The Netherlands seems to have the most generous regime for preventive measures. The Spatial Planning Code is the applicable regime that codifies the égalité principle. However, contrary to Flanders, it is not clear for burdened parties in which case they can expect compensation and in which can they cannot. This is because the normal social risk is incorporated in a minimum threshold of at least $2 \%$ of the value of the property, which can vary from case to case.

\section{Recovery strategy}

The recovery strategy has not developed in the Netherlands, as is the case for Flanders and France. France has theoretically the most elaborated public-private regime, CAT-NAT. The insurance against floods is mandatory, which is possible because the state provides a fall back mechanism through the Central Reinsurance Company. One of the aspects that makes this system remarkable is the fact that it is interwoven with the prevention strategy. Not only pours a part of the insurance premiums into preventive measures, but also there is a connection between the insurance and the PPRi obligation of municipalities. Insurance companies can amend a reduction of the insured capital when the community has not established a PPRi. Companies may also refuse to insure property that was illegally built in unbuildable zones. However, some authors criticise the system, because in practice insurance companies do not always use the abovementioned possibilities. ${ }^{114}$ Also in Flanders there is fall

114 Larrue and others, supra n. 9. 
back mechanism by the state - the Flemish Disaster Fund. Almost all citizens are insured against floods, because it is part of the fire insurance. Premiums can be differentiated by the flood risks of a specific area, through which also a strong connection is made with the prevention strategy. However, a real test of this system has not occurred yet. The Dutch system is completely state-oriented. The government can apply a specific Act, the Calamities Compensation Act, in case a flood is declared a disaster. In that case, the state compensated part of the loss. Currently only one pilot of a flood insurance exists. This is a private initiative, which will not be copied by other insurers without a fall-back mechanism from the state, even though in literature an increasing interest for flood insurance can be identified. ${ }^{115}$

\subsection{Causes of unequal distribution}

The differences in the elaboration of specific compensation regimes and the will to compensate are connected to the elaboration of specific FRM strategies. Van Doorn-Hoekveld explained differences between these three countries through, among others, non-legal reasons, such as the water policy and spatial planning policy divide and the public-private divide. ${ }^{116}$

Although the countries differ greatly, they have one important thing in common: the core of the égalité principle is visible in most of their legal regimes, even though in some cases case law explicitly opposes it. ${ }^{117}$ This is not surprising, because the core of the principle - people may not bear an individual and excessive burden caused by an interference with property rights for the public interest is also visible in the criteria of Article 1 First Protocol ECHR. ${ }^{118}$ However, the interpretation of these criteria of the égalité principle differ substantially in the studied countries. The Netherlands has created the broadest scope: it applies the égalité principle for indirect damage as well. France has a very narrow scope, under which the burden must be extraordinary large to be eligible for compensation when it is caused through a public interest objective. In Flanders, it is still uncertain how the application of the égalité principle will develop for preventive FRM measures.

115 W.J.W. Botzen \& J.C.J.M. van den Bergh, 'Insurance against Climate Change and Flooding in the Netherlands: Present, Future, and Comparison with Other Countries.' (2008) 28 Risk analysis: an official publication of the Society for Risk Analysis 413; I. Seifert and others, 'Influence of Flood Risk Characteristics on Flood Insurance Demand: A Comparison between Germany and the Netherlands' (2013) 13 Natural Hazards and Earth System Science 1691; V. Bruggeman, M. Faure \& M. Haritz, 'Remodelling Reparation: Changes in the Compensation of Victims of Natural Catastrophes in Belgium and the Netherlands' (2011) 53 Disasters 766; M. Faure, 'In the Aftermath of the Disaster: Liability and Compensation Mechanisms as Tools to Reduce Disaster Risks' (2016) 52 Stanford Journal of International Law 95. Van Doorn-Hoekveld, supra n. 38.

17 CE 29 June 2016, N³75020, ECLI:FR:CECHR:2016:375020.20160629.

118 The criteria are similar to Article 1 First Protocol ECHR. 
Following the description and the comparison, two legal causes of these differences can be distinguished. The causes are connected to the fragmentation of FRM governance - the water policy and spatial planning divide - and the division of responsibilities - the public-private divide-. These two causes lead to an internal inconsistency of compensation in the three countries, which leads to unequal distribution of burdens.

\subsubsection{Cause: Water policy and spatial planning policy divide}

A compensation regime is tied to the authority that is competent to act in the field of FRM. Therefore, the authority competent to compensate damage differs per strategy. This paper shows that the compensation regimes between the prevention, protection and recovery strategy vary and may lead to different outcome, which threatens the equal distribution of burdens. Although the material criteria of the égalité principle are visible in the most of the compensation regimes, the counties do not apply it in a consistent way in the protection and prevention strategy. The Dutch Water Act and Spatial Planning Act codified the égalité principle. In France, the criteria of the égalité principle are also visible in the regime for compensation loss caused by public easements and in the Decree on Integrated Water Policy and in Flanders the core of the principle is visible as well. Especially Flanders and France, do not automatically compensate loss caused by preventive measures and, for indirect damage, no compensation is possible at all. This leads to the conclusion that adverse effects are not equally distributed in the relevant FRM strategies. Another important notion in this respect is that this can potentially hamper the equal distribution of adverse effects when shifting from one strategy to another. In the Netherlands, the fear of no-fault liability claims - the compensation of preventive FRM loss - forms a serious threat from changing from protection towards prevention. ${ }^{119}$

\subsubsection{Cause: The public-private divide}

The Dutch State is responsible for water management and private parties still have limited responsibilities. However, for the compensation of loss, people tend to look at the State to provide a solution. The fact that the state limits its responsibility for FRM and compensation explains why a private system of insurances does not develop in the Netherlands in the recovery strategy. Nevertheless, the state provides the compensation in case it is necessary. $^{120}$

119 This is visible in interviews with stakeholders and expert meetings the author conducted for the STAR-FLOOD project.

120 A nuance should be made, that in the Netherlands, thresholds to 'fill in' the abnormal burden are extensively used to limit the amount of compensation. 
In contrary to Dutch citizens, Flemish private parties have more responsibilities in the field of FRM. This is evident in the facts that they need to insure themselves against flooding, that there is a duty to inform potential buyers of flood risks of property, and that compensation of indirect damage is not common. Furthermore, the égalité principle is not as visible and applied as in the Netherlands. A less elaborated compensation regime, with less obligations to compensate lawfully caused loss, could lead to an easier shift between protection and prevention.

France is the opposite of the Netherlands, France is characterised by very strict compensation regimes for loss caused in the public interest in the field of FRM and urban planning. The public-private divide is a leading explanation of this difference. In France, FRM was traditionally the responsibility of the individual. Indeed, only recently has the state taken the responsibility for FRM. At that stage, no-fault liability regimes were already developed for other fields of governmental action. Another important concept in France is that, when the State acts in the public interest in the field of FRM and urban planning, it is very unusual to compensate the resulting loss. For spatial planning easements, the law codified the non-compensation principle, although exceptions are also included in the law. Thus, the law does not infringe Article 1 First Protocol ECHR. Even the existence of the égalité principle does not lead to much compensation in the field of FRM. Instead, that principle is seen as a last resort in case no codified compensation regime is present. Compensation regimes, although very strict, are present for preventive and protective FRM measures. The private responsibility is also present in the recovery strategy. Even though the CAT-NAT regime cannot exist without a strong state influence, all citizens pay for the extra insurance and some can be punished for living or building in ‘danger' zones.

\subsubsection{Consequence: Internal inconsistency of distribution of burdens in FRM strategies}

The way adverse effects are distributed among society differs per strategy in the studied countries. The Netherlands is the most consistent. For each strategy, the general means are used to compensate disproportional adverse effects of measures, which is fully in line with the égalite principle. When the Flemish Decree on Integrated Water Management is applicable, a greater number of adverse effects are compensated, than when the Spatial Planning Act is applicable. For the instrument Water Test, no compensation is provided, just as is the case for indirect damage. However, since the Constitutional Court broadens the scope of the égalité principle, this could lead to a more generous regime in the future. In France, the solidarity characterises the recovery strategy: loss caused by floods is compensated by the fund filled by 
insurance premiums of approximately 95-98\% of French citizens. ${ }^{121}$ This differs largely from burdens that a small group bears from measures that are needed to prevent a disaster from happening, just as is the case in Belgium. It depends on the adverse effect whether a burdened party get compensation or not. Ex post compensation is better arranged and more generous in both countries than ex ante or preventive compensation. This leads to the conclusion that distributional effects are not spread fairly among society in both countries. Of course, this contrast can be explained by the fact that the public interest causes preventive adverse effects, and natural incidents causes ex post damage. Thus, actions for the public interest do not automatically lead to compensation in both countries. However, since the tendency to move from reactive FRM towards preventive FRM also leads to different distributional - adverse - effects, it would suit both countries to scrutinize the existing compensation regimes for the preventive strategies and see whether they are as solidary as their ex post regimes. Moreover, because a small group bears the burdens that benefits the society as whole, not only because the measures that causes their burdens prevent floods, but also prevent the insurance funds to compensate loss caused by floods, which may lead to lower insurance premiums. This does not mean that the Netherlands cannot learn from Flanders and France as well. By providing the possibility to claim compensation in almost all cases - preventive phase as well as recovery phase - there is rarely an incentive to move away from areas with a high flood risk. The Netherlands should deal with this problem in the future, just as the rather low flood risk awareness, because the state cannot guarantee $100 \%$ safety. Especially new developments in flood prone or potentially flood prone areas should be scrutinised. Although these kind of developments will probably not lead to excessive burdens that must be compensated, because citizens should be aware of the risks they are facing in such areas.

\section{Conclusion}

The paper shows that differences exists between the compensation regimes of the strategies and countries. Every strategy is characterised by its own compensation regimes. Not one compensation regime is equipped to deal with a shift of strategies in the sense that one compensation regime could compensate adverse effects in all strategies. For a fair distribution of burdens, the égalité principle can be used in the prevention strategy, as well as the protection strategy. The conditions of this principle are in line with art. 1 First Protocol ECHR and present in the studied compensation regimes of all

${ }^{121}$ Yoshida \& Banba, supra n. 110, p. 436. 
countries. The implementation of the principle, however, leads to completely different outcome in the prevention strategy.

The paper concludes that distributional effects of FRM are spread in the most consistent way in the Netherlands. Although the compensation of distributional effects in Flanders and France is not consistent in the strategies, they do not seem to infringe Article 1 First Protocol ECHR, and therefore, revisions of the systems are not necessary. The Belgian and French recovery strategy is indeed based on solidarity and yet, solidarity seems to lack in the compensation regimes for especially the prevention strategy. Especially since the focus of FRM has shifted from recovery or ex post to prevention, both countries should review how the distributional effects of FRM can be spread more fairly among society. In the Netherlands, a different tendency is visible. The state cannot guarantee $100 \%$ safety from flooding, and thus should reconsider also other strategies, not only prevention and protection. The Netherlands should find ways to create more awareness of flood risks and to reduce the dependence of citizens of the state for compensating adverse effects.

The fact that a very elaborated compensation regime might hamper a shift from one strategy to another, as is the case in the Netherlands, is another interesting conclusion, that demands multidisciplinary research. How the role of the compensation regime influences FRM strategies does not only have legal implications, but political and social implication as well. This paper fills the knowledge gap with regard to the legal distributional effects of FRM, but must be seen as a starting point for joint cooperation with other disciplines to look deeper into the last aspect raised.

\section{Acknowledgments}

The author would like to thank her supervisors prof. dr. H.F.M.W. van Rijswick, prof. dr. B.J. Schueler and dr. G.M. van den Broek for their comments, suggestions and discussions on earlier versions. She also would like to thank dr. B. Barraqué, dr. P. De Smedt and the anonymous reviewers for their valuable reflection on the draft version and J. Reynolds for editing the English of a near-final version. 